\title{
全国悉皆アンケート調査による従来型特別養護老人ホームの ユニットケア実施状況と効果

\author{
CURRENT SITUATIONS OF GROUP LIVING AND THE EFFECT \\ IN TRADITIONAL NURSING HOMES FOR THE ELDERLY FOUND \\ BY THE COMPLETE ENUMERATION SURVEY THROUGHOUT JAPAN
}

\author{
足立 啓*, 安岡真由 ${ }^{* *}$, 品川靖幸***, 林 悦子**** \\ Kei ADACHI, Mayu YASUOKA, Yasuyuki SHINAGAWA \\ and Etsuko HAYASHI
}

\begin{abstract}
The complete enumeration questionnaire survey throughout Japan concerning current situations of group living for the elderly was conducted in 5216 traditional nursing homes. The contents of the investigation are whether or not they introduce group living, how they manage the care for group living, when they started, and what effects cause the elderly and care givers. As a result, about 27 percent of the answering facilities provide group living, and about 60 percent of group living facilities evaluated the positive effects to the elderly with BPSD.
\end{abstract}

Keywords : Nursing home for the elderly, Group living, Making to small scale, Effect 特別養護老人ホーム, ユニットケア, 小規模化, 効果

\section{1.はじめに}

日本は、急速な高齢社会にともない利用者主体の高齢者福祉保健 サービスの充実が求められるなか、2000年 4 月から高齢者介護 保険制度が施行された。2002 年には、施設における生活環境の 質を重視したケアを実現するため、個室・ユニットケアを特徵とす る制度（いわゆる新型特養）が設けられ、これまでの集団処遇型の ケアから個人を尊重したケアへと転換し始めた。

全国の特別養護老人ホームは、圧倒的多数がその制度前に建設さ れた多床室、大食堂や長い廊下などからなる施設 (以下、従来型特 養) である。しかし、従来型特養でも個室・ユニットケアを志向し たケアの環境改善が求められている。従来型特養のユニット化への 転換には、ハード・ソフト両面で様々な制約条件や課題を抱えており、 環境改善は容易ではなく、その手法も明らかではない。また、今ま での調查・研究の中でも全国悉皆で従来型特盖のユニットケアの実 態を把握したものはない注1)。

本研究は、従来型特養に扔けるユニットケアの実態把握を行うた め、全国の従来型特盖 5216 施設を対象に、ユニットケア実施（以 下、実施施設）あるいは未実施（以下、未実施施設）状況など、ユニッ トケアの実態に関するアンケート調査を行った。単純集計の結果は、 既に分析・発表しているが1）2）3）4、ユニットケアの実態と従来型
施設職員の意識などの二次分析は、まだ着手していない。そこで 本稿では、全国規模での実態と効果に対する職員の意識を把握、分 析することで、ユニットケア未実施施設に対する大きな示唆を与え ることができるのではないかと考え、ユニットケアの実態と効果、 竣工年、延床面積、階数、定員などとの関係について分析すること を目的とする。

\section{2. 研案植零

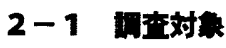

全国従来型特養におけるユニットケアの実態把握を行うため、全 国悉皆アンケート調查を実施した。調查対象は、平成 16 年 6 月 1 日現在で小規模生活単位型特養 (新型特養) を除外した、全ての従 来型特養 5216 施設注2) である。アンケートは、施設長または施 設全体の運営を実質的に統括し、現場も熟知している方に回答を求 めた。

\section{2-2 调主法}

アンケートは $\mathrm{A}$ 票と $\mathrm{B}$ 票で構成され、A 票は全ての調查対象に回 答を求め、 $\mathrm{B}$ 票は $\mathrm{A}$ 票で「ユニットケアを実施している」と答えた 施設に回答を求めた。

\footnotetext{
* 和歌山大学システム工学部環境システム学科 教授・博士 (工学)

** 和歌山大学大学院システム工学研究科 博士前期課程

*** 松下電工侏) 修士 (工学)

**** 東京都老人総合研究所 協力研究員 $\cdot$ 博士 (工学)

Prof., Dept. of Environmental Systems, Wakayama Univ., Dr. Eng.

Graduate School of Systems, Wakayama Univ.

Matsushita Electric Works, Ltd., M. Eng.

Research Assoc., Metropolitan Institute of Gerontology, Dr. Eng.
} 
本調査におけるユニットケアは、以下に示す 3 点により定義した。

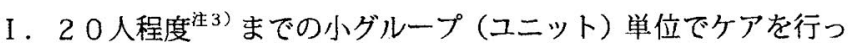
ている。

II. 各ユニットごとに食事を摂ったり、お茶を飲むりビングスペー スやコーナーがある。

III. 原則、職員は固定配置とする。

これらは、小規模生活単位型の介護報酬基準とは異なるが、でき る限り全国的に従来型特養のユニットケアの実態把握を行うために 独自に定義した。ユニット定員については、小規模生活単位型の 10 人以下と同じでは、従来型でのユニットケアの実態把握が十分 できないと考え（今まで従来型特養では人数の定義がないので）、目 安注3) となるものから 20 人程度と定義した。アンケート実施期間は、 平成 17 年 1 月〜 2 月である。

\section{2-3 期堂内客}

$\mathrm{A}$ 票の内容は、I 施設概要 (建築概要、定員等)、I ユニットケア の実施状況（ユニットケア実施の有無）、四ユニットケアを実施して いない理由と今後の導入予定である。

B 票の内容は、I ユニットケア実施状況（開始時期、ユニットに 分ける際の基準等)、II 勤務体制（職員配置等）、III チームケア（看 護職員、栄養士等のユニットでの業務内容)、 $\mathrm{N}$ 運営内容 (入浴、排 泄、整容、食事等)、V施設と設備、VIニットケアの実施効果、VII 今後の方向性、VIII自由記述である。

\section{2-4 分析方法}

アンケートの有効回答数は、A 票 1575 施設（回収率 $30.2 \%$ )、B 票 429 施設（回収率 $8.2 \%$ 、A 票回答施設の $27.4 \%$ ) である。このデータを統計プログラムパッケージ S P S $\mathrm{S}$ for Windows と Excelを用い単純集計とクロス集計(カイ2 乗検定) を行った。

\section{3. 結整と考果}

\section{3-1 ユニットケア弯入状況（图 1・图 2・图3・图 4)}

アンケート調査より、従来型特養でのユニットケア実施状況を把 握した。従来型特養 1575 施設のうち、実施施設は 429 施設 (27.2\%) であり、未実施施設は 1146 施設と 7 割以上を占め ている(図 1)。

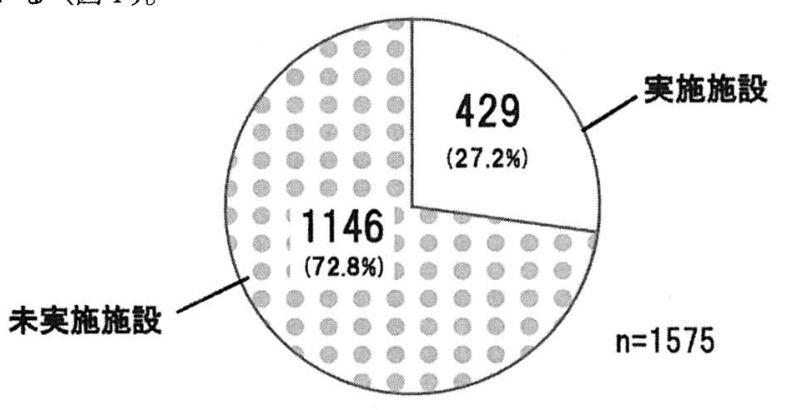

圆1 ユニットケア導入状況

実施施設の今後の意向は、半数以上を占める 223 施設 $(52.0 \%)$ が、今後も従来型特湌でユニットケアを続けていく意向を示す（図 2)。そのうちの 119 施設（27.2\%）が、改修等を行いユニッ トケアを実施していく意向を示し、改修等をせずに引き続き従来型
特養で実施が 104 施設である。全ユニットに小規模生活単位型を 導入する意向を示した施設は 41 施設（9.6\%）にすぎない。

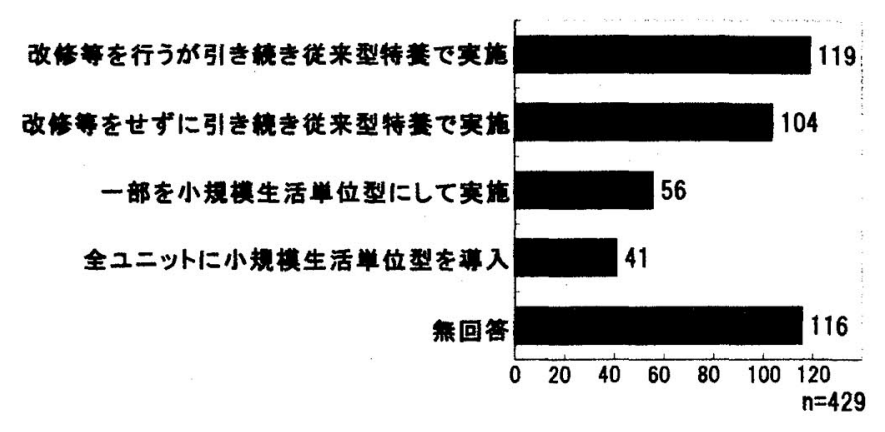

國 2 実施施設の意向

また、未実施施設の今後の導入意向は「導入を計画中」が 379 施設（3 3.1\%)。「導入はしたいが計画はしていない」が 352 施 設（30.7\%) である(図 3 )。

つまり、未実施施設のうち 731 施設（6 3.8\%）が今後導入する 意向を示している。その中でも 243 施設（3 3.2\%）が「一部小 規模生活単位型となるよう改修等して導入」する意向を示し、また、 237 施設（32.4\%）が「従来型特養のまま改築等して導入」す る意向である（図 4)。以上のことより、従来型特養のままユニット ケアを実施していく意向が多いことが明らかになった。

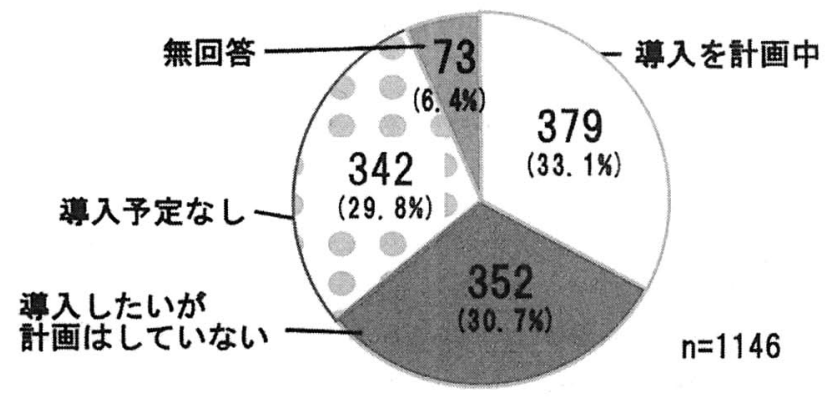

图 3 未実施施設の導入意向

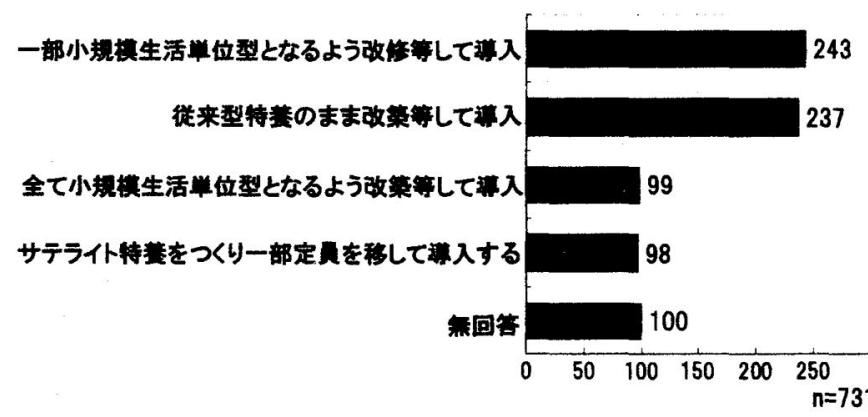

國 4 末紧施施没の向

\section{3-2 ユニットケアの实施状況（国5～图11・戠1）}

\section{(1)ユニット槛成}

従来型の施設は新型特養のように空間が小規模に分かれていない。 小規模空間を作るためには何らかの方法で空間を区切る必要がある。 ユニット間の分節は、「その他」と回答した施設が最も多く、110 施 設（2 $5.6 \%$ ）である。その内容として、ガーデニング用ラティス、 カーテン、スクリーン、グリーンなどがあった。

「その他」「無回答」以外では、「ついたて」と回答した施設が最も 
多く 88 施設 (2 0.5\%)、次いで「固定の壁」が 83 施設 ( $19.3 \%)$ である。さらに、のれんや家具といった家庭的な方法で区切ってい る施設もみられる(図 5 )。

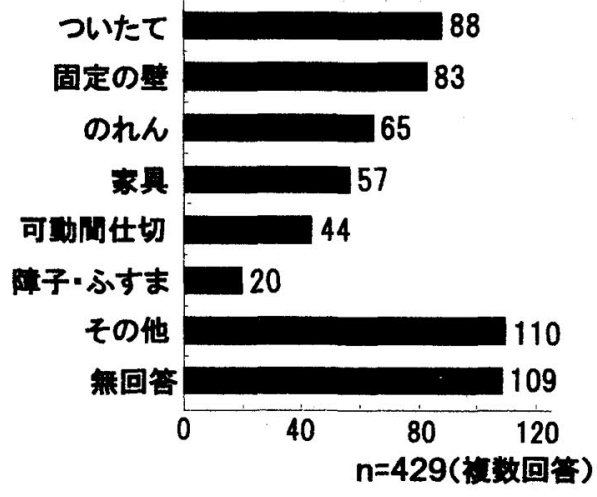

圆5 ユニット間の分節

1 施設のユニット数は「3」の施設が最も多く 107 施設 (2 $4.9 \%$ ）で、「4」ユニットは 106 施設（24.7\%）である。 また、ユニット数「10以上」は、18施設 (4.2\%) である（図6）。

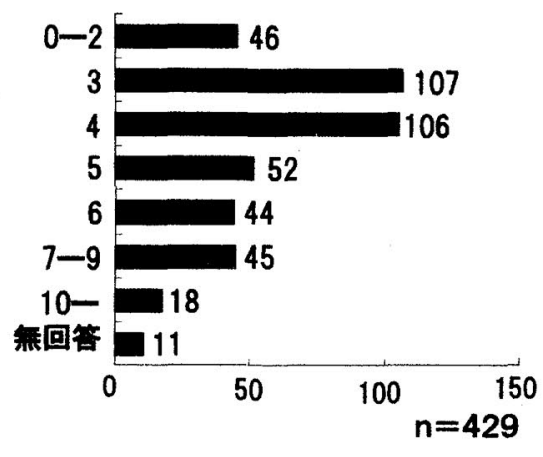

國 61 施設あたりのユニット平均数

\section{(2)入俨者の状呮}

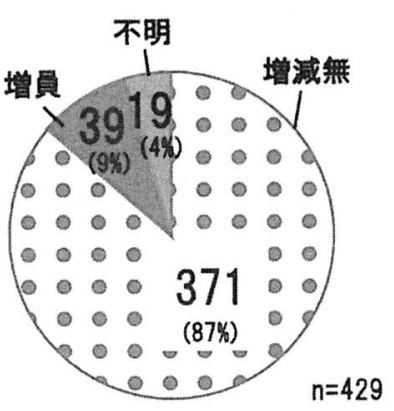

图 7 这?这数の変化

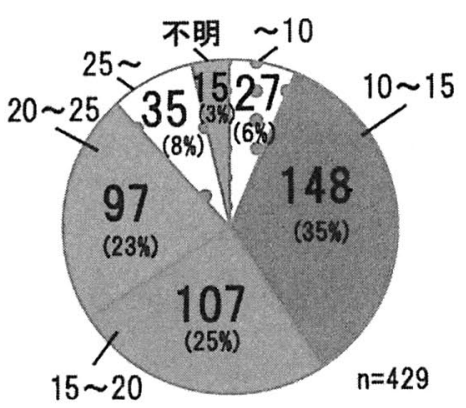

國8 ユニットの平均人数
ユニットケア導入時の入居定員の増减は「増減無」が 371 施設 （86.5\%) で最も多い。減員した施設は存在しない。また、増員 した施設は 39 施設（9.1\%）である（図 7)。1 ユニットの平均 人数は 148 施設 $(34.5 \%)$ が「10 人以上 15 人未満」として いる。1 ユニット「 10 人未満」は 27 施設（6.3\%）にとどまっ ている（図 8)。全施設での 1 ユニット平均人数は 14 人であり、新 型特養の基準である 10 人程度にはいたらない。
入居者をユニットに分ける際に、基準がある施設は 275 施設 (6 $4.1 \%$ ) である。そのうち 204 施設 (7 4.2\%)が「ADL 別」, 194 施設 ( $70.5 \%$ ) が「認知症症状別」の基準を設けている。 また「相性別」の基準設定は144 施設（52.4\%）である（図9）。

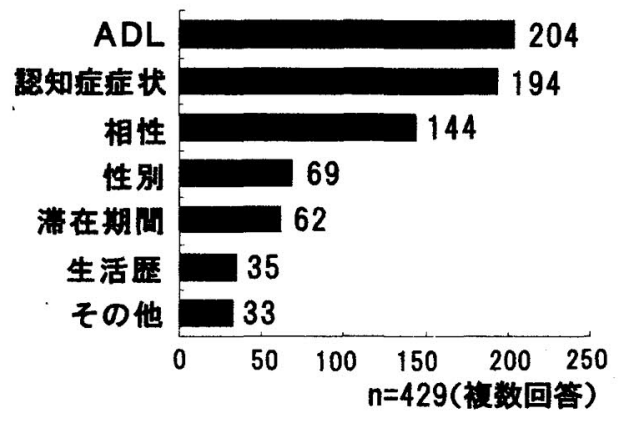

国9 ユニット分けの基準

\section{(3)㜔罢体制}

介護職員の配置状況は「昼間のみユニットを固定し、夜間は固定 していない」が2 22 施設 (5 1.7\%) と約半数である。「昼夜間 とも固定」が185施設（43.1\%）である。「ユニットに固定し ていない」 11 施設（2.6\%）である（図 10 ）。

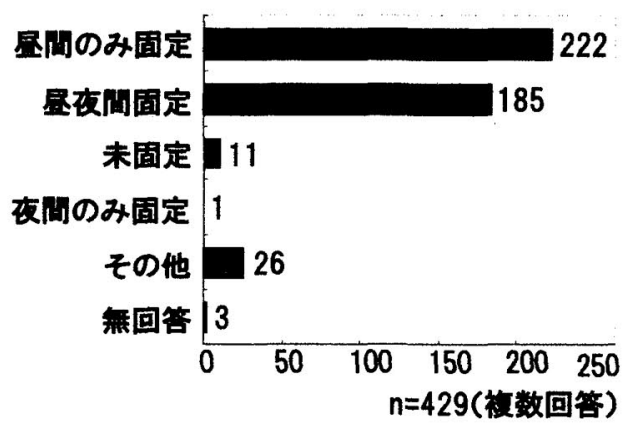

图 10 介護職員の配置状浣

\section{(4) 国法の分第化}

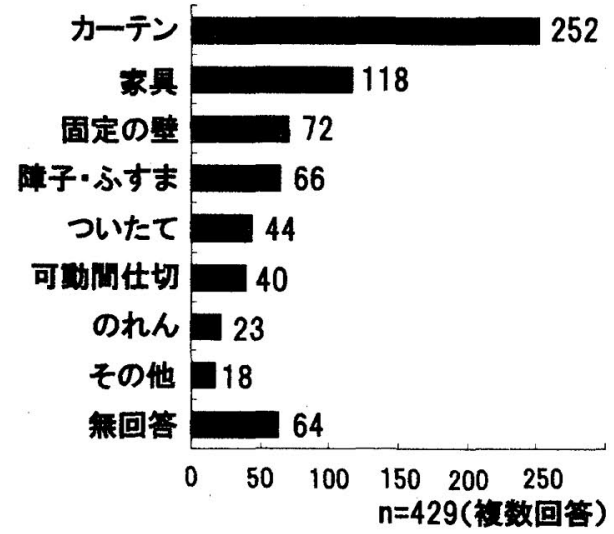

图11 多床華の仕切り

全室個公でケアを実施する施設は 45 施設（１０．５％）にすぎず、 ほとんどの施設が多床室 $(2$ 人部屋や 4 人部屋)でケアを行っている。 252 施設 ( $58.7 \%$ ) が多床室内の仕切りに「カーテン」を利用 している（図 11 )。

しかし、カーテンのみでは個別的空間を作り出すことは不可能であ 
る。多床室主体の従来型特養においても「家具」や「固定の壁」の ように「カーテン」以外の間仕切りも整備され始めている。

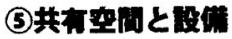

リビング、ダイニング、トイレ、キッチン、風呂を全ユニットに 設置が○、それ以外を×として分類した（表 1 ）。

衰 1 共有空間・設備

\begin{tabular}{|c|c|c|c|c|c|}
\hline リビング & ダイニング & トイレ & キッチン & 風呂 & 施設数 \\
\hline \multirow{16}{*}{0} & \multirow{8}{*}{0} & \multirow{4}{*}{0} & \multirow{2}{*}{0} & 0 & 33 \\
\hline & & & & $x$ & 105 \\
\hline & & & \multirow{2}{*}{$x$} & 0 & 3 \\
\hline & & & & $x$ & 73 \\
\hline & & \multirow{4}{*}{$x$} & \multirow{2}{*}{0} & 0 & 3 \\
\hline & & & & $x$ & 16 \\
\hline & & & \multirow{2}{*}{$x$} & 0 & - \\
\hline & & & & $x$ & 21 \\
\hline & \multirow{8}{*}{$x$} & \multirow{4}{*}{0} & \multirow{2}{*}{0} & 0 & - \\
\hline & & & & $x$ & 1 \\
\hline & & & \multirow{2}{*}{$x$} & 0 & - \\
\hline & & & & $x$ & 9 \\
\hline & & \multirow{4}{*}{$x$} & \multirow{2}{*}{0} & $\mathrm{O}$ & - \\
\hline & & & & $x$ & $=$ \\
\hline & & & \multirow{2}{*}{$x$} & 0 & - \\
\hline & & & & $x$ & $=$ \\
\hline \multirow{16}{*}{$x$} & \multirow{8}{*}{0} & \multirow{4}{*}{0} & \multirow{2}{*}{0} & 0 & 1 \\
\hline & & & & $x$ & 6 \\
\hline & & & \multirow{2}{*}{$x$} & 0 & 3 \\
\hline & & & & $x$ & 23 \\
\hline & & \multirow{4}{*}{$x$} & \multirow{2}{*}{0} & 0 & - \\
\hline & & & & $x$ & 4 \\
\hline & & & \multirow{2}{*}{$x$} & 0 & - \\
\hline & & & & $x$ & 15 \\
\hline & \multirow{8}{*}{$x$} & \multirow{4}{*}{0} & \multirow{2}{*}{0} & 0 & - \\
\hline & & & & $x$ & 3 \\
\hline & & & \multirow{2}{*}{$x$} & 0 & - \\
\hline & & & & $x$ & 79 \\
\hline & & \multirow{4}{*}{$x$} & \multirow{2}{*}{0} & 0 & - \\
\hline & & & & $x$ & 5 \\
\hline & & & \multirow[t]{2}{*}{$x$} & 0 & - \\
\hline & & & & $x$ & 26 \\
\hline
\end{tabular}

O:全ユニットに設需 $\times$ :全ユニットに設置なし

設置状況は、62.5\%でリビングをユニット毎に設置してい る。また、7 $1.8 \%$ でユニット毎にダイニングを設置している。 $41.3 \%$ $\%$ ユニット毎にキッチンを設置している。トイレはほぼ居 室毎に設置が $35 \%$ 、浴室をユニット毎に設置しているのは $10 \%$ である。リビングの設置、次いでダイニングさらにはキッテンといっ た順で共有空間が整備される傾向がある。従来型施設では、同一施 設内でも種々のハード制約条件があるため、全ユニットに整備が行 き届かない施設が 26 施設ある。これは、従来型施設ゆえの長い廊下、 大食堂など、小規模ユニット化を困難にする建築・設備条件による ものと考えられる。

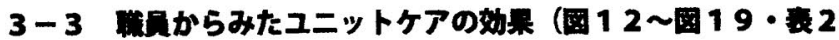 (1)入居者に対する勃基}

「入居者の認知症の周辺症状」をはじめ、ほとんどの項目で「良く なった」と答えた施設が半数である。「入居者間のコミュニケーショ ン」や「家族の満足」は特にユニットケアの効果として高く評価し ている。しかし、入居者の健康状態は「変わらない」と回答した施 設が 204 施設 (47.6\%) で、「良くなった」と答えた 172 施 設（４０.1％）を上回る。全体的には、「悪くなった」と評価した 施設は少ない。

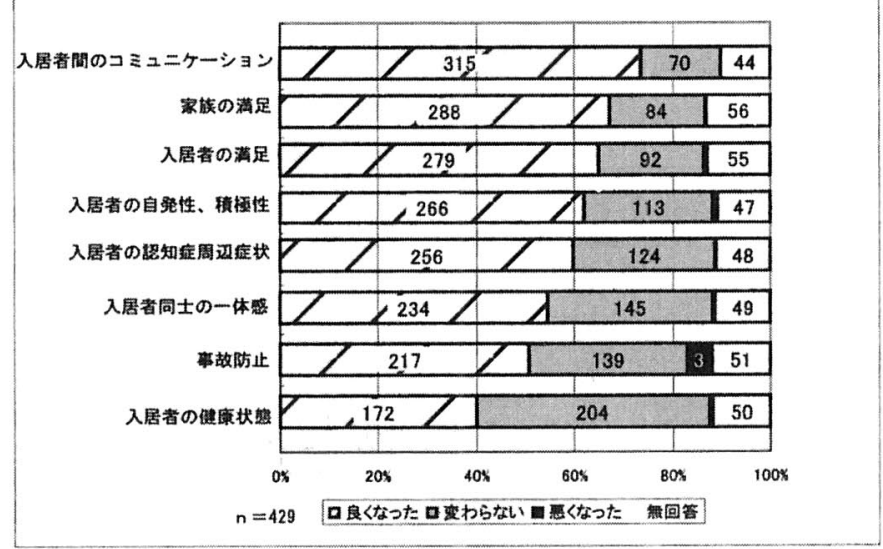

圆 12 入居者に対する効果

\section{(2)僬異に封する効基}

「入居者との信頼・顔馴染みの関係づくり」「入居者の変化に気づ いた早期の対応」「一対一のケア」といった入居者との直接的な関わ りに関する項目で「良くなった」と回答している施設が 7 割をこえる。 「動線や移動距離の減少」では「悪くなった」が他の項目より多い。

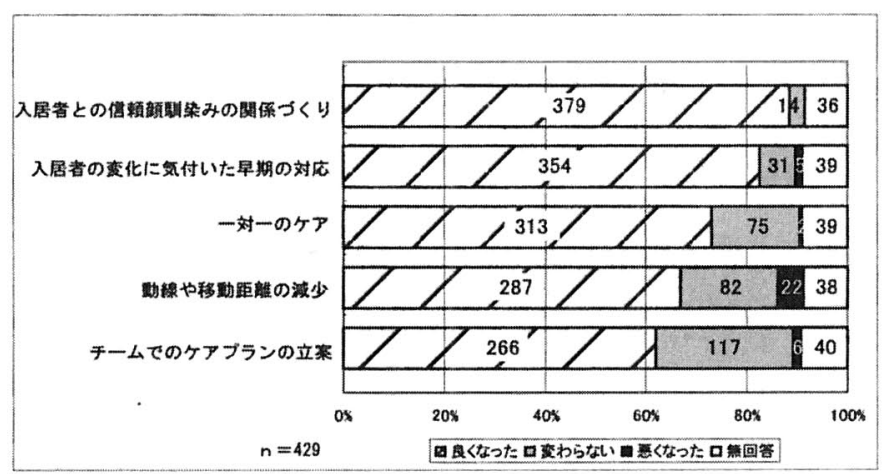

图13 職員に対する効果

(3)家旗・地域に対する奻果

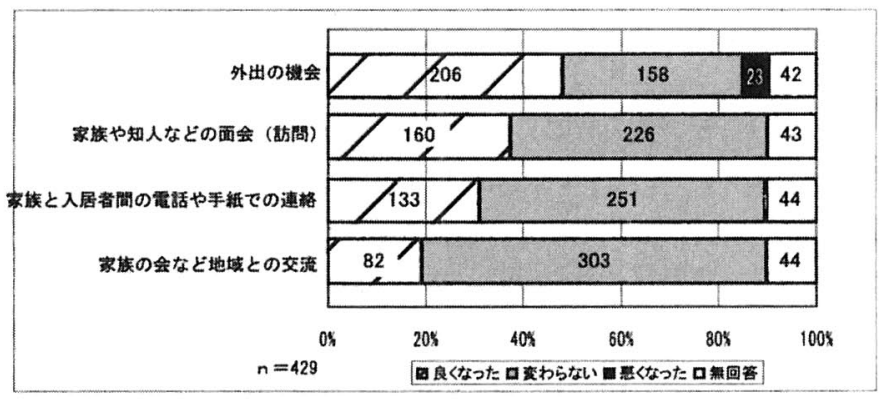

圆 14 家族・地域に対する効果 
入居者や職員に対する効果より、家族・地域に対する効果は全般 的に「変わらない」が多い「「外出の機会」が「多くなった」と評価 した施設が約半数あるが、「少なくなった」としている施設の割合も、 他の項目より多い。

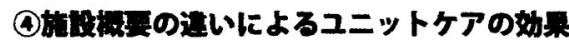

実施施設 429 施設の施設概要（竣工年、延床面積、階数、定員、 ユニット平均人数、職員体制、個室率、設備設置状況、リビング、 ダイニング、キッチン、トイレ、浴室、工事の有無）とユニットケ ア効果の関係を把握するため、クロス集計を行い、カイ 2 乗検定を した。クロス集計における施設概要の詳細（1４アイテムのカテゴ リーとそのサンプル数）を注 4 に示す。表 2 はカイ 2 乗検定により 有意差のみられたユニットケア効果と 5 アイテムの結果を示す。

施設概要とユニットケアの効果

\begin{tabular}{|c|c|c|c|c|c|}
\hline & 竣工年 & 浴室 & 定冒 & $\begin{array}{l}\text { 延床 } \\
\text { 面積 }\end{array}$ & $\begin{array}{l}\text { 工事の } \\
\text { 有無 }\end{array}$ \\
\hline $\begin{array}{c}\text { 入居者の } \\
\text { 認知症周辺症状 }\end{array}$ & * & - & - & - & - \\
\hline $\begin{array}{c}\text { 入居者の } \\
\text { 自発性・楀楆性 }\end{array}$ & - & - & - & - & - \\
\hline $\begin{array}{c}\text { 入居者間の } \\
\text { コミュニケーション }\end{array}$ & - & - & - & - & - \\
\hline $\begin{array}{l}\text { 入居者同士の } \\
\text { 一体感 }\end{array}$ & * & * & - & - & - \\
\hline $\begin{array}{l}\text { 入居者の } \\
\text { 僻康状態 }\end{array}$ & - & - & * & * & - \\
\hline 事故防止 & - & - & - & - & - \\
\hline 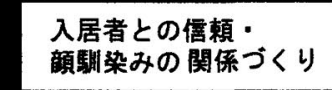 & - & - & - & - & - \\
\hline $\begin{array}{c}\text { 入居者の变化に诵づいた } \\
\text { 早期の対応 }\end{array}$ & - & - & - & - & * \\
\hline 一対一のヶア & - & - & - & - & - \\
\hline 動線や移動距離の減少 & - & - & - & - & - \\
\hline
\end{tabular}

\section{(4)-1 入居者に対する奻暴}

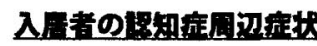

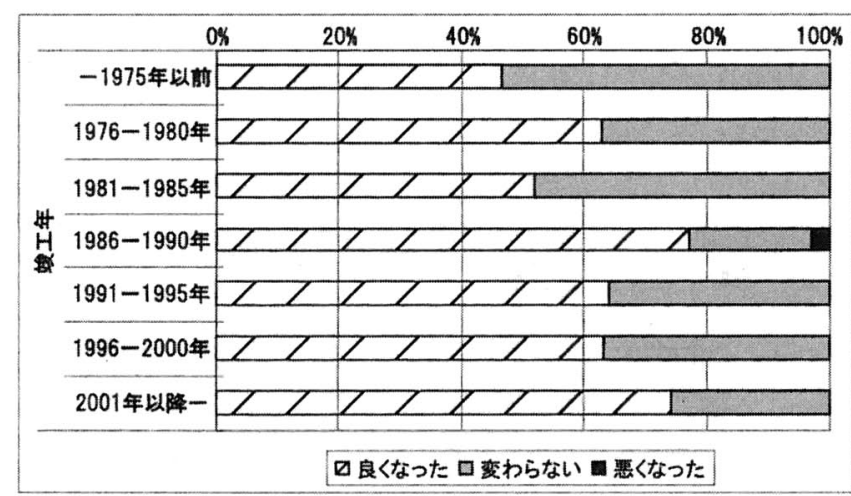

图 15 入居者の認知症周辺症状
全体の「入居者の認知症周辺症状」は、「良くなった」は $59.7 \%$ 、変

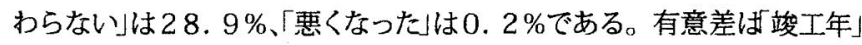
にみられた。竣工年が新しくなるにつれて「良くなった」と評価した割 合が増加し、古い施設ほど「変わらないと答えた割合が増加傾向で ある。

このことから、竣工年が新しい施設ほど、ユニットケアを実施し て入居者の認知症周辺症状が「良くなった」と評価した割合が増加 傾向であるが、古い施設ほどその施設で長く生活している入居者が 多く、生活環境の変化に適応するにも時間がかかり、評価に差が現 れたのではないかと考元られる。全体の傾向では「良くなった」と 評価した施設は約 6 割と多く、ユニットケアを実施して入居者の認 知症周辺症状改善に、「良い」結果につながっている。

\section{入最都国土の一坋}

「入居者同士の一体感」は、全体では「良くなった」は $54.5 \%$ 、 「変わらないは $33.8 \%$ 、「悪くなった」は $0.2 \%$ あるる。

有意差は「竣工年」と「浴室の設置状況」にみられた。竣工年が 新しくなるにつれて「良くなった」と評価した割合が増加し、古い 施設ほど「変わらない」と答えた割合が増加する。このことから、 「入居者の認知症周辺症状」と同様に、生活環境の変化に適応するに も時間がかかると推測される。今後、ユニットケアを継続させてい くと結果的には「変わらない」と答えた古い施設でも「良くなった」 と評価する施設が増加するのではないかと予想される。

「浴室の設置状況」については、「全ユニット」を除き、「施設に1 つ」の方が入居者同士の一体感は「良くなった」と評価した割合は 増加傾向である。また、「全ユニット」に設置施設では、悪くなった」 と評価した施設もある。この結果は、ユニットケアを実施して「全 ユニット」に浴室が設置されると、1 つのユニット内で生活が完結 し、小規模生活が可能になり、ユニットケアの効果も「良くなった」 が増加すると予想していたが、予想に反した結果となった。

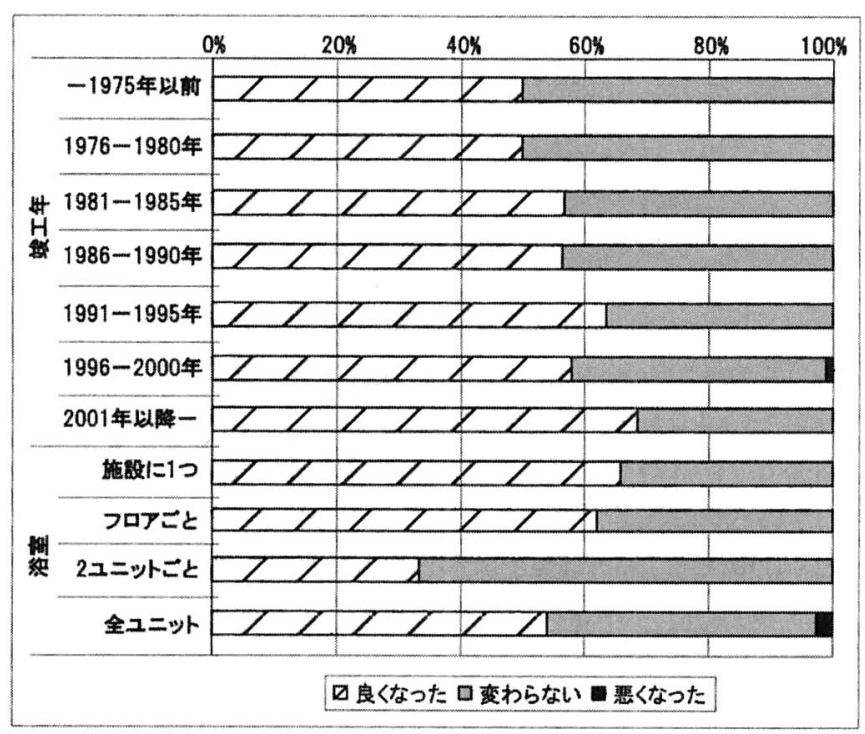

圆 16 入居者同士の一体感

次に、図 17 は設備設置状況別にみた各ユニットケアの効果につ いて示している。上にいくほど設備設置状況がよくなっていること を示していて、それぞれの設備設置状況の効果について示したもの である。特に有意差は見られなかったが、LDTKBなどが各ユニット 


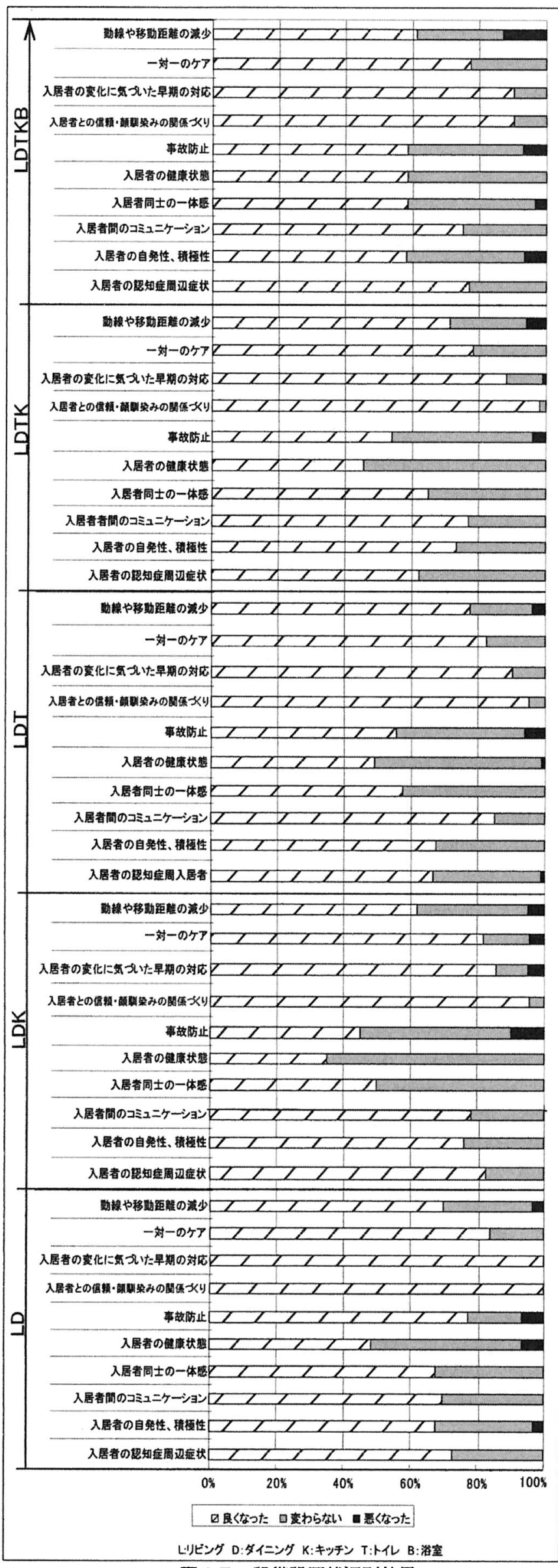

圖 17 設備設置状涀別効果
に設置されることで、ユニットケアの効果は「良い」とはいえない 現状が明らかになった。この結果より、L D T K Bなどが各ユニッ トに設置されなくても、ケア体制等の様々な要因でハード条件を補 い、試行錯䛊しながら従来型特養でも、ユニットケアの効果が十分 に得られる可能性が示唆された。

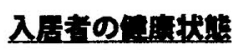

「入居者の健康状態」は、全体では「良くなった」は $40.1 \%$ 、変 わらない」は $47.6 \%$ 、「悪くなった」は $0.7 \%$ \%ある。

有意差は「延床面積」と「定員」にみられた。延床面積が $3000 \mathrm{~m}^{2}$ 以上では、「良くなった」と「変わらない」の評価した施 設数は同じくらいであるが、3000 m満の施設では「良くなっ た」よりも「変わらない」と評価した割合が多い。2000 $\mathrm{m}^{2}$ 末満 では、「悪くなった」と評価した施設もあった。これより、延床面積 が $3000 \mathrm{~m}^{2}$ 以上の大規模施設でユニットケアを実施した施設の場 合、入居者の健康状態に「良い」効果を与えていることが示唆された。 定員は、60人以上の施設では「良くなった」と評価した割合が 増加傾向である。延床面積同様に、定員が多く、大規模施設により 効果がみられた。

以上より、「入居者の健康状態」については施設規模が大きいほど ユニットケアの効果は「良いと評価していることが明らかになった。

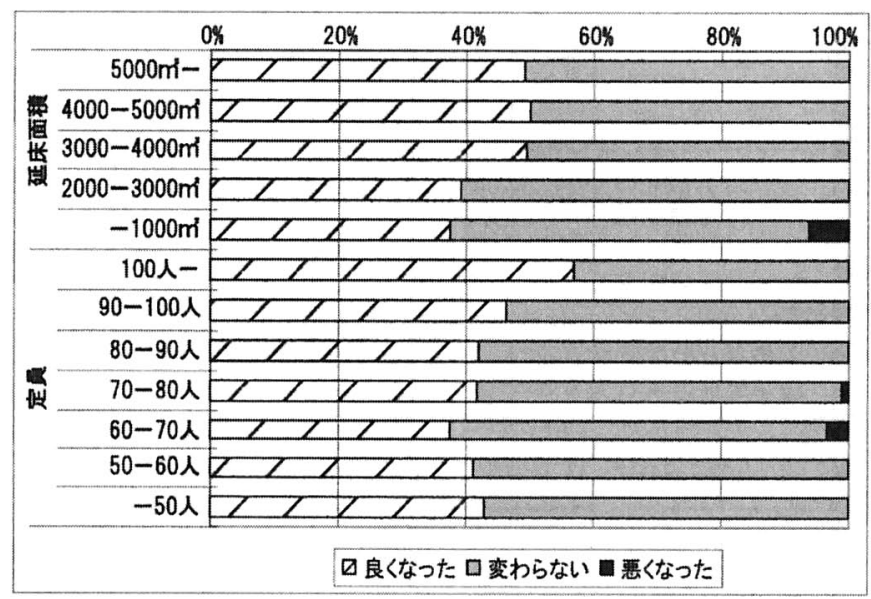

图 18 入居者の健康状態

\section{(4)-2 敞员に対する奻果}

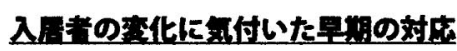

入居者の体調変化や事故防止などに気付いた早期の対応をユニッ トケア実施の有無で検討する。

「入居者の变化に気付いた早期の対応」は、全体では「良くなった」

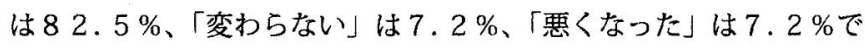
ある。

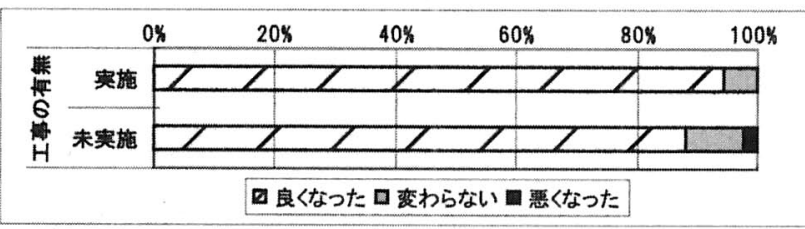

国 19 入居者の変化に気付いた早期の対応

有意差は「工事の有無」にみられた。ユニットケア塞施に伴い、 工事を実施している施設の方が「良くなった」と評価した割合が高い。 
一方、未実施施設では「悪くなった」と評価した施設も見られたが「良 くなった」も8割以上みられ高い評価を示している。

結果より、ユニットケアに伴い何らかの工事を実施し、ハード条 件を整えた方が「良くなった」と評価した割合は高いが、「工事の有 無」に関わらず、従来型特養でユニットケアを実施することにより 「入居者の変化に気付いた早期の対応」は 8 割以上が「良い」と高く 評価し、より個別ケアへと志向している状況が同える。

\section{4. まとめ}

全国悉皆アンケート調查により、従来型特養のユニットケアの実 施状況と効果について分析を行った。以下に結果を要約する。

なお、回答施設の概要は、注 4 に示した通りである。

(1) 従来型特養でユニットケアを実施している施設は $27 \%$ \%ある。 そのうちの約半数が従来型のハードのままでユニットケアを継 続する予定である。また未実施施設では、6 4 \%が実施したい 意向を示し、今後、従来型特養でのユニットケア実施施設は增 加すると予想される。

（2）従来型のユニット化に際しては、リビング、次いでダイニング、 キッチンなどの順で共有空間を確保する傾向が見られた。また、 個室は 1 割に過ぎないが、多床室（9 割）の領域化、リビング の分節化が計られるなど、従来型においてユニット化に向けた 様々な工夫が見られた。

（3）ユニットケアについての効果は、入居者と職員に対する効果は 全体的に「良くなった」と評価が高い。入居者への効果につい ては、「入居者の周辺症状」、入入居者同士の一体感」「入居者の 健康 状態」に効果が見られた。職員への効果については、「入 居者の変化に気付いた早期の対応」に効果が見られた。 しかし、地域・家族への効果は「変わらない」の評価が多い。

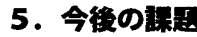

本稿では施設単位でユニットケアの現状と効果について分析・考 察を行った。従来型施設のユニットケアは同じ施設であってもユニッ トごとで実態の違いが明らかになった。同一施設内でも条件 (形態、 規模、人数など）が異なるために、施設単位でなくユニット単位で の検討が必要である。この課題については、別稿で検討予定である。 現時点では、個室・ユニットケア（10人程度）の小規模生活単位 型の介護報酬が主である。2005 年 4 月に準ユニットケアが創設さ れたが、多様な従来型のユニットケアをさらに評価する柔軟な介護 報酬上の評価も必要ではないかと考えられる。

\section{韵辞}

本アンケート調査は、「平成 16-17 年度厚生労働科学研究費補助 金 (長寿科学総合研究事業)」(主任研究者：足立啓）による。

本アンケート作成には同時期に小規模生活単位型特養に関する研 究調査 ${ }^{5)}$ を実施した井上由起子氏（国立保健医療科学院）・松原茂 樹氏 (大阪大学大学院工学研究科) から多くの助言を頂いた。 本調查の実施には（株）三菱総合研究所の協力を得た。 また論文作成には岩本明日香氏(和歌山大学大学院)の助力を得た。 ここに記して、関係者各位ならびに、調查にご協力頂いた施設の 方々に謝意を表します。

\section{考文柱}

1）品川靖幸（ほか 3 名）：全国アンケート調查による従来型施設のユニット ケアの実態、その 1 3、建築学会大会学術梗概集 2005 年度、pp337 $\sim 342 、 2005.9$

2) 安岡真由 (ほか 2 名) : ユニットケア実施の現状把握 従来型特別養謢老 人ホームにおけるユニットケア環境に関する研究、その 1 〜 築学会大会学術梗概集 2006 年度、pp25 28、2006.9

3）主任研究者 足立啓：従来型施設における痴呆性高龄者環境支援指針の 適用による環境改善手法の開発と効果の多面的評価、厚生労働省科学研 究費補助金（長寿科学総合研究事業）平成 $16-17$ 年度 総合研究報告 書、 2006.3

4）足立啓（ほか 3 名）：全国悉皆アンケート調查による従来型特別養護老人 ホームのユニットケアの実態について、日本建築学会技術報告集 第 25 号、2007.6、pp243 246

5）日本福祉建築協会：小規模介護単位型特別養護老人ホームにおけるサー ビスの実態と評価手法の開発に関する研究報告書、2005.3

\section{注}

注 1 ）全国規模の、従来型特養のユニットケアの現状についての詳細な調查 研究はない。しいてあげれば、全国老人福祉施設協議会が隔年で行う「全 国老人ホーム基礎調查」があるが、無作為抽出による（約 1000 施設） の限定調查であり、ユニットケアに特化した調查ではなく、ユニット の定義もされていない。

注 2) WAM NET 登録の全国の特別養護老人ホーム総数から、平成 16 年度 の小規模生活単位型の介護報酬を受けている 198 施設 ${ }^{5)}$ を削除した 5216 施設を本調查対象とした。

注 3 ）平成 14 年度全国老人福祉施設協議会による「全国老人ホーム基礎調査」 (1021 施設無作為抽出) では、ユニットケア実施 327 施設の打ち分け は、 10 人以下 $(7 \%) 。 11$ 人- 15 人 $(17 \%) 、 16$ 人- 20 人 $(29 \%)$ であり、20人以下が過半 $(53 \%)$ を占めることから、本研究における 全国悉皆の従来型ユニットケア実態把握には 20 人程度が適当であると 判断した。

注 4） 4 頁の「施陪概要の違いによる効果」の施設概慗の14アイテムとそ れらに属するカテゴリーと単純集計結果を以下に示す（カテゴリー数 $63)$ 。

\begin{tabular}{|c|c|c|c|}
\hline 理工年 & 延床面掼 & 整数（地上） & 定㑹 \\
\hline 2001 年以湔 $(n=124)$ & -2000 m林济 $(n=55)$ & 1F $(n=125)$ & -50 人未来洋（n=16） \\
\hline 1996-2000年（n=88） & 2000-3000n海 $(n=105)$ & $2 F \quad(n=137)$ & $50-60 人 \quad(n=45)$ \\
\hline 1991-1995年（n=69） & 3000-4000自未湍 $(n=112)$ & $3 F \quad(n=101)$ & $60-70 人 \quad(n=69)$ \\
\hline 1986-1990年 $(n=38)$ & 4000-5000m米消 $(n=61)$ & $4 F \quad(n=38)$ & $70-80 \curlywedge \quad(n=107)$ \\
\hline 1981-1985年（n=28） & 5000 m以上 $\quad(n=62)$ & $5 F \quad(n=20)$ & $80-90 人 \quad(n=53)$ \\
\hline 1976-1980年（n=31） & & & $90-100$ 人 $\quad(n=28)$ \\
\hline -1975年以䪨（n=18） & & & 100人以上- $(n=111)$ \\
\hline ユニット平均人数 & 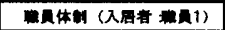 & 個至事 & 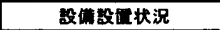 \\
\hline -10人未沙 $(n=27)$ & -2 未浻 $(n=54)$ & $100 \% \quad(n=35)$ & 全ユニッHにLDTKB $(n=34)$ \\
\hline 10-15人来湍 $(n=148)$ & $2-2.5$ 未消 $(n=213)$ & $75-100 \% \quad(n=11)$ & 全ユニットl=LDTK（n=112） \\
\hline 15-20人未滥（n=107） & 2.5-3末洴 $(n=84)$ & $50-75 \% \quad(n=17)$ & 全ユニッN=LDT（n=111） \\
\hline 20-25人未滥（n=97） & 3以上- $(n=31)$ & $25-50 \% \quad(n=91)$ & 全ユニット $=L D K （ n=23)$ \\
\hline 25 人以上- $(n=35)$ & & $0-25 \% \quad(n=270)$ & 全にユニットに=LD（n=36) \\
\hline リビング & タイニング & キッチン & ML \\
\hline 全ユニット $(n=263)$ & 全בニット $(n=306)$ & 全ユニット (n=177) & ほぼ居宣こと（n=154） \\
\hline 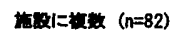 & 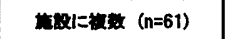 & 一部工二ット ( $n=99)$ & ユニ朴内に分儌 $(n=117)$ \\
\hline 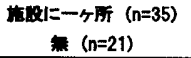 & 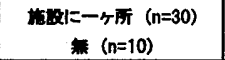 & 네 $(n=139)$ & ユニット内に \\
\hline 溶室 & 工事の有繁 & & \\
\hline 全ユニット $\quad(n=44)$ & 实望 $(n=185)$ & & \\
\hline $\begin{array}{c}\text { 2ユニットこと }(n=13) \\
\text { フロフこと }(n=98)\end{array}$ & 未实坊 $(n=244)$ & & \\
\hline then $=13 \quad(n=208)$ & & & \\
\hline
\end{tabular}

（2006年11月10日原稿受理，2007年10月15日採用決定） 